\title{
Veri zarflama analizinin ormancılıkta kullanımı
}

\author{
Mahmut M. Bayramoğlu ${ }^{\text {a,* }}$, Devlet Toksoy ${ }^{a}$
}

\begin{abstract}
Özet: Devlet orman işletmeleri, ormancılık faaliyetlerinin en yoğun gerçekleştiği ekonomik birimlerdir. Devlet orman işletmelerinin varlıklarını gerçek anlamda devam ettirebilmeleri ancak sahip oldukları üretim araçlarını etkin kullanabilmeleriyle mümkündür. Bu noktada etkinlik kavramı ve ölçümü ön plana çıkmaktadır. Veri zarflama analizi, son yıllarda özellikle kar amacı gütmeyen kamu kurumlarının etkinlik düzeylerini ölçme de kullanımı artan, parametrik olmayan doğrusal tabanlı bir yöntemdir. Bu yöntem, birimleri birbirinden farklı birçok değişkenin aynı anda kullanımına izin vermesinin yanında, analize sokulan birimlerin birbirleriyle karşılaştırılmalarına da imkan vermektedir. Bundan dolayı, devlet orman işletmelerinin etkinlik düzeylerinin belirlenmesinde veri zarflama analizinin kullanımı, karar vericilere uygulamada ve yorumlamada kolaylıklar sağlayacaktır.
\end{abstract}

Anahtar kelimeler: Veri zarflama analizi, Etkinlik, Devlet orman işletmesi

\section{Uses of data envelopment analysis in forestry}

\begin{abstract}
In Turkey, State Forest Enterprises are accepted as the most intensive economic units for forestry activities. The sustainability of state forest enterprises can be obtained by efficient usage of their resources. Recently, Data Envelopment Analysis is based on the non-parametric linear method, which provides the efficiency level for the public institute without any profit purpose. This method allows to use many different variables in the same time, in addition, it can enable to be compared with each other. Because of this fact, especially the determination of the efficiency levels of state forest enterprises will provide easy way for decision makers in application and assessment process though Data Envelopment Analysis in Turkey.

Keywords: Data envelopment analysis, Efficiency, State forest enterprise
\end{abstract}

\section{Giriş}

Yeryüzündeki kaynakların hızla tükendiği günümüzde, ülkeler ihtiyaçlarının mümkün olan en üst düzeyde karşılanabilmesi için ciddi kararlar almak zorundadırlar. Üretim olanaklarının ülke sinırlariyla kısıtlı olacağı değerlendirildiğinde, mevcut kit kaynakların kullanım şekilleri hayatiönemi taşımaktadır. Üretim faaliyetlerinin en uygun şekilde yapılıp yapılamadığ 1 ise, mikro ve makroekonomi açısından günümüz dünyasının en önemli sorunu durumundadır (Demirci, 2012). Bununla birlikte gittikçe karmaşıklaşan üretim süreçleri ve her geçen gün daha da artan rekabet baskısı, iş letmelerin başarılı olmasını, rakiplerine karşı avantaj elde etmesini ve uzun dönemde de bu avantajlarını korumasinı zorunlu kilmaktadır. İşletmelerin rekabet avantajı sağlamaları, bilgi birikimlerine göre verecekleri kararlara bağlıdır. Bu durum, işletmelerin karar verebilmesine yönelik bilgiye olan ihtiyac1 arttırmaktadır (Şafak, 2009). Bu ihtiyaç da, modern işletmecilik anlayışının özünü oluşturan verimlilik ve etkinliğin ölçümü konusunu ön plana çıkarmaktadır (Yeni, 2012). Etkinlik ve verimlilik çoğunlukla kavramları birbirleriyle eș anlamlı kullanılmaktadır. Verimlilik daha çok teknik bir durumu vurgulamaktadır. Etkinlik ise, iş letmelerin sahip oldukları kaynak potansiyeli ile iş letmeler tarafindan kullanılan bölümü arasındaki ilişkiyi incelemektedir. Ancak verimlilik, kaynakların kullanımı ile elde edilen çıktı arasındaki ilişkiyi değerlendirmektedir (Yükçü ve Atağan, 2009). Verimlilik tanımlayıcı, etkinlik ise kuralcı bir kavramdır. Etkinliğin nasıl hesaplanacağının kuralları, yol ve yöntemleri bellidir (Subhash, 2004). Genel anlamda etkinlik, bir işletmenin veya örgütün tanımlanmış amaçlarına ve stratejik hedeflerine ulaşmak amacıyla gerçekleştirdikleri faaliyetlerin sonucunda, bu amaç ve hedeflere ulaşma derecesini belirleyen bir performans boyutudur. Etkinlik hedeflerin ne ölçüde başarıldığını ve bir faaliyetin planlanan etkisi ile gerçekleşen etkisi aras indaki ilişkiyi göstermektedir (Arslan, 2002). Kavramsal açıdan etkinlik birçok alanda kullanılmaktadır. Buna göre ekonomik etkinlik; kaynakların veya malların bir kısmının yeniden dağılımı ile kendi değer yargıları içerisinde diğer kişileri daha kötü konuma getirmeden, insanların bir kısmını veya tamamını, yine kendi değer yargıları içeris in de, daha iyi konuma getirme imkanının olmadığ 1 bir durum olarak tanımlanmaktadır (Yaylalı, 2004). Teknik etkinlik ise; bir karar birimi, herhangi bir çıktıyı artırmak için en azından başka bir çıktıyı azaltmak veya girdiyi artırmak; herhangi bir girdiyi azaltmak için de en azından başka bir girdiyi artırmak veya çıktıyı azaltmak zorunda kalıyorsa, teknik olarak etkindir şeklinde tanımlanmaktadır (Koopmans, 1951). Her iki tanımda incelendiğinde konunun Pareto optimali çerçevesinde düşünüldüğünü görülmektedir. Bu kapsamda Koopmans'in ekonomi literatürüne kazandırdığ 1 etkinlik kavramı, Pareto-Koopmans teknik etkinliği olarak
${ }^{\text {a }}$ KT Ü Orman Fakültesi, Orman Mühendisliği Bölümü, 61080, Trabzon
${ }^{*}$ Corresponding author (İletişim yazar1): mahmud@ktu.edu.tr

$\checkmark$ Received (Geliş tarihi): 06.12.2016, Accepted(Kabul tarihi): 13.02.2017
Citation (Atıf): Bayramoğlu, M.M., Toksoy, D., 2017. Veri zarflama analizinin ormancilikta kullanımı. Turkish Journal of Forestry, 18(1): 82-93.

DOI: $\underline{10.18182 / \mathrm{tif} .273413}$ 
adlandırılmıştır (Subhash, 2004). Etkinlik ölçümde iki ampirik yaklaşım bulunmaktadır. Bunlardan biri parametrik yaklaşımdır. Bu yaklaşımda üretim fonksiyonunun şeklinin is tatis tiks el olarak hem biliniyor hem de tahmin edilebiliyor olduğu kabul edilmektedir. Parametrik olmayan yaklaşımda ise hiçbir üretim fonksiyonunun şekli varsayım olarak ele alınmaz. Bunun yerine daha iyi bir pratik fonksiyon, gözlenen girdi ve çıtılardan ampirik olarak oluşturulmaktadır (Zeydan, 2005). Veri Zarflama Analizi (VZA) kamu kuruluşlarının, yani kar amacı gütmeyen iş letmelerin performansını ölçebilmek için geliştirilmiş olan doğrusal programlama tabanlı ve parametrik olmayan bir yöntemdir. VZA, birbirinden farklı ölçülerle ölçülmüş ya da farklı ölçü birimlerine sahip girdi ve çıktı değerlerinin karşılaştırılmasının güç olduğu durumlarda karar verme birimlerinin (KVB) göreli performanslarını oluşturarak en uygun kararın alınmasina yardımes olan bir analizdir (Charnes vd.,1989). Analizin temelinde benzer türden KVB'nin üretim etkinliklerinin değerlendirilmesi yer alır. Analiz konu olacak KVB'nin aynı hedefe yönelik benzer iş levler görmesi, aynı pazar şartlarında çalış ması ve gruptaki bütün birimlerin verimliliklerini nitelendiren etmenlerin, yoğunluk ve büyüklüklerindeki farklılıklar hariç, aynı olmas 1 şartları aramaktadır (Karsak ve İşcan, 2000).

Bu çalışmada, son yıllarda özellikle kamu sektöründe faaliyet gösteren işletmelerin performanslarını ölçmede kullanılan veri zarflama analizinin ormancılık alanında kullanımı irdelenmiştir. Bu kapsamda literatürde yer alan çalışmalar detaylı bir şekilde incelenerek Türkiye ormancıllğgnda bu yöntemin kullanılabilirliği ortaya konulmuştur.

\section{Etkinlik ölçümü}

Ekonomik anlamda kaynakların sınırlı olduğu günümüzde etkinlik ve verimlilik gibi konular önemini her zaman korumuş ve korumaya devam etmektedir. Özellikle günümüzde varolan rekabet, firmaları kaynaklarını optimal, başka bir ifade ile en etkin şekilde kullanmaya itmektedir. Dönemsel olarak firma yöneticileri firmanın hedeflenen planlarından sapmaları belirlemek, rakiplerine karşı piyasadaki konumunu görmek amacı ile ölçümlere ve değerlemelere ihtiyaç duymaktadırlar (Yalama ve Sayım, 2008). Etkinlik ölçümü yardımıyla, incelenen firma ya da işletmelerin, girdilerinin çıktılara dönüştürme sürecinde ortaya çıkan etkin olmayış ları belirlenebilmektedir. İşletme, etkin olmayışı ıaynağını tanımlayarak üretim verimliliğini, dolayısıyla kazancını artırmak ve mali yapısını güçlendirmek olanağına kavuşmaktadır. Ayrıca, işletme sektörde rekabet ettiği diğ er işletmeler arasında bulunduğu konumu belirleme şansına da sahip olmaktadır. Bu amaçlarla yapılan etkinlik ölçümü, oran analizi, parametrik yöntemlerve parametrik olmayan yöntemler olmak üzere üç ana başlık altında toplanmaktadır (Çağlar, 2003).

\subsection{Oran analizi}

Oran analizi, kolay uygulanabilirliği ve diğer yöntemlere göre daha az veri gerektirmesinden dolayı performans ölçümünde kullanılan en yaygın yöntemdir. $\mathrm{Bu}$ yöntemde tek bir girdi ve çıtı incelenebilmekte ve birden çok girdinin ve çktının değerlendirilmesinde yetersiz kalmaktadır. Çok sayıda girdi ve çıktı kullanılması gerekliliği taşıyan ekonomik etkinlik ölçümlerinde oran analizini kullanmak pek uygun değildir (Kıran, 2008). Oran analizi, tek boyutludur (Kaya ve Aktan, 2011) ve tek bir oranın seçilmesinden dolayı işletmenin performansına ilişkin değişik boyutlar hakkında yeterince bilgi sağlayamamaktadır. Oran analizinde her bir oranın ayrı ayrı değerlendirilmesi sonucunda işletme bazı oranlara göre etkin, bazı oranlar için ise etkin olmayan olarak nitelendirilebilmektedir. Dolayısıyla, işletmenin etkinliği konusunda karar vermek güç olmakta ve yorumlanmas1 olanaksız durumlar ortaya çıkabilmektedir (Çingi ve Tarım, 2000). Ayrica etkin olmayan olarak bulunan birimlerin etkin duruma geçmeleri için bir öneri sunulamamaktadır (Thanas soulis vd., 1996). Çok sayıda orana başvurarak bilgi sahibi olmak ise oldukça maliyetleri arttırmakla birlikte yanıltıcı göstergelerin oluşmasına neden olabilmektedir.

\subsection{Parametrik yöntemler}

Parametrik testler; ilgili parametreye, belirli bir dağılıma ve varyans kavramına dayanarak işlemler yapan esnek olmayan is tatistiks el yöntemlerdir (Karagöz ve Ekici, 2004).

$\mathrm{Bu}$ yöntemlerde, etkinlik ölçümü yapılacak sektörlere ilişkin üretim fonksiyonunun analitik bir yapıya sahip olduğu varsayımı yapılır ve bu fonksiyonun parametrelerinin belirlenmesine çalışı1ır (Bates vd., 1996).

Parametrik etkinlik ölçüm yöntemlerinin en yaygın olanı aralarında neden sonuç iliş kisi olduğu bilinen, bağ ımlı ve bağımsız değişkenler arasındaki ilişkinin nedensel yapısını belirlemeye yönelik bir yöntem olan regresyon analizidir. Regresyon analizi, bilinen bulgulardan, bilinmeyen gelecekteki olaylarla ilgili tahminler yapılmasına izin verir. Regresyon analizinde, değişkenler arasındaki ilişkiyi fonksiyonel olarak açıklamak ve bu ilişkiyi bir modelle tanımlayabilmek amaçlanmaktadır. Parametrik yöntemlerde genel olarak bir gözlem kümesi bulunmaktadır. $\mathrm{Bu}$ küme içinde en iyi performansin regresyon çizgisi (etkinlik sinırı) üzerinde olduğu varsayılarak, bu çizgiden sapma göstermeyen gözlemler etkin; bu gözleme göre başarısı olan diğer gözlemlerde etkinsiz olarak tanımlanmaktadır.

Regresyon analizi sonucunda elde edilen regresyon denklemi bağımsız girdi miktarlarıyla, bağımlı çıktı miktarı arasındaki ilişkiyi verdiği için üretim fonksiyonu olarak düşünülebilmektedir. Ancak, bir üretim fonksiyonu, tanım gereği belirli girdi düzeyinde üretilebilecek maksimum çıktı miktarın 1 gösterirken, regresyon analiziyle bulunan üretim fonksiyonu ortalama değer vermektedir. Regresyon analizinin etkinlik ölçümünde kullanılmasının yarattığ sakıncalar etkinlik ölçümünün en yüks ek performans yerine ortalama performansa göre yapılmas inın yanında sadece tek bir çıtı faktörünün bulunabilmesi ve gözlemlerden hareketle elde edilen ortalama üretim fonksiyonunun endüstri içindeki çeşitliliği değerlendirememesi ve tüm üretim birimlerinin aynış ekilde üretim yaptığ 1 vars ayımında bulunmasidir (Tarım, 2001).

\subsection{Parametrik olmayan yöntemler}

Parametrik olmayan yöntemler; parametreye, belirli bir dağılıma ve varyans kavramına dayanmadan iş lemler yapan, genellikle veriler yerine onların siralama puanların kullanarak işlem yapan esnek istatistiksel yöntemlerdir 
(Özdamar, 2002). Parametrik yöntemlere alternatif olarak ortaya çıkan parametrik olmayan yöntemlerde üretim fonksiyonunun yapısı hakkında her hangi bir analitik biçim öngörülmemektedir. Bu açıdan parametrik yöntemlerden daha esnek bir yapıya sahiptir. Ayrıca girdi ve çıktı sayısının birden çok olduğu durumlarda da rahatlıkla kullanılmaktadır (Çağlar, 2003). Etkinlik sınırına olan uzaklığın ölçülmeye çalışıldığı bu yöntemlerde genellikle matematiksel programlamadan yararlanılmaktadır (Çukur, 2005).

Etkin sınırdan sapmaları etkinsizlik olarak değerlendiren parametrik olmayan yöntemler, çok girdi ve çok çıktı bulunan bir üretim sürecini bütün olarak ele alabilmektir. Parametrik olmayan yöntemlerin, farklı ölçü birimlerindeki üretim faktörlerini ortak bir paydada buluşturmak için ihtiyaç duyulan ağırlıklandırma iş lemini ortadan kaldırması, bu yöntemlerin, diğ er yöntemlerden üstünlüğünü sağlayan bir diğer özelliktir. Bu özelliklerine ek olarak, parametrik olmayan yöntemlerin, göreli etkinlik ölçümlerinde çok yaygin kullanılmasinın temel nedenleri arasında farklı uzmanlıkları olan, fakat aynı ürünleriüreten veya hizmetleri sunan karar birimlerinin özelliklerini dikkate almas1, üretim ekonomis inin teorik çevresiyle uyum içinde olmas 1, etkinlik skorunu oluşturan etkinlik bileşenlerini belirleyebilmesi sayılabilir (Gözü, 2003).

Etkinlik ölçüm modellerinin birbirlerine göre üstün ve zayıf yönleri bulunmaktadır. Önemli olan ölçülmek is tenen duruma karş1 en uygun modelin seçilmesidir. Üte (2002) çalışmasında analiz tekniklerini aşağıdaki şekilde sınıflandırarak karş ılaş tırmış tır.

\section{Veri zarflama analizi}

İşletmeler amaçlarını gerçekleştirebilmek için, dış çevreden sağladıkları girdileri, belirli bir üretim teknolojisinden yararlanarak mal ve hizmet biçiminde çıktılara dönüştürmekte ve günümüzün yoğun rekabet koșulları altında, üretim süreci içerisinde, kıt kaynaklarını etkin bir biçimde kullanmak durumundadirlar. İşletmeler rekabet ettikleri ve yaşamlarını sürdürdükleri sektör içinde, diğer işletmelerle arasındaki teknik etkinlik farklarını bilmelidirler. Negatif yönde ortaya çıkacak olan bir teknik etkinlik farkı, kaynaklarını israf ettiklerinin göstergesi olmaktadır. İşletmeler, sektör içinde teknik etkinliği en yüksek olan işletmeyi kendilerine referans olarak seçip, kaynak kullanım ya da üretim düzeylerinin her hangi birini, referans olan işletmeye yaklaştırmalıdırlar. İșletmelerin is tenilen çıtı düzeylerini elde etme sürecinde, girdilerini ne ölçüde kullandıklarının belirlenmesinde göreli etkinlik ölçümleri çok önemli bir yere sahiptir (Avc1, 2004). İşletmelerin, göreli etkinlik ölçümünde kullandıkları en yaygın yöntem olan VZA'da KVB'lerin girdi ve çıktıları incelenerek, en iyi performansa sahip olanlar seçilir ve bu KVB'ler kullanılarak etkin sınır oluşturulur. Oluşturulan bu etkin sınırın üzerinde yer almayan birimlerin etkin olmama dereceleri yine bu etkin sınıra göre belirlenir (Bayazitlı ve Çelik, 2004). Optimal girdi bileşimiyle elde edilebilecek en yüksek üretim miktarlarının oluşturduğu bu teorik sınıra etkin üretim sınırı denir (Aktaş, 2001). VZA, herhangi bir gözlem kümesi içinde en az girdi bileşimini kullanarak en çok çıktı bileşimini üreten "en iyi” gözlemleri, diğer bir ifadeyle etkinlik sınırını oluşturan KVB'leri belirler. Söz konusu sinır "referans" olarak kabul edip, etkin olmayan KVB'lerinin bu sınıra olan etkinlik düzeylerini radyalolarak ölçer. VZA çoklu girdi ve çıtı değişkenlerinin bir doğrusal programlama modelinde kullanılarak her bir gözlem için bir tek etkinlik skorunun elde edilmes ini sağlar (Depren, 2008).

Analiz sürecinde elde edilen etkin KVB'lerin oluşturduğu etkin üretim sınırının çizimindeki zarflama sürecinden dolayı yöntemin adı VZA olarak belirlenmiştir.

VZA'nın göreli etkinliği ölçme şekli, iki aşamalı olarak kıs aca şu şekilde özetlenebilir;

- Herhangi bir gözlem kümesi içinde en az girdi bileşimini kullanarak en çok çıktı bileşimini üreten "en iyi" gözlemleri ( ya da etkinlik sınırını oluşturan karar birimlerini) belirler,

- Söz konusu sınırı "referans" olarak kabul edip, etkin olmayan karar birimlerinin bu sinıra olan uzakliklarını (ya da etkinlik düzeylerini) "radyal" olarak ölçer (Yolalan, 1993).

VZA'nın kullanılabilmesi için öncelikle aynı kararların uygulandığ 1 ve benzer organizasyona sahip olan karar verme birimlerinin seçilmesi gerekmektedir. Karar verme birimlerinin etkinliğinin ölçülebilmesi için bu birimlere ait girdi ve çıtı değişkenleri belirlenmelidir. VZA modelinin ayrıştırma yeteneğinin çok iyi olabilmesi için girdi ve çıktı sayısının çok olması arzulanır. $\mathrm{Bu}$ nedenle mümkün olduğunca çok sayıda girdi ve çıktı elemanı seçilmelidir. Ancak seçilen girdi ve çıktı elemanlarının her karar birimi için kullanılıyor olması gerekmektedir. Ayrıca seçilen girdi sayıs1 $m$, çıktı sayısı da $p$ ise en az $m+p+1$ tane karar birimi araştırmanın güvenilirliği açısından gerekli bir kısıttır. Diğer bir kısıt ise değerlendirmeye alınan karar verme birimi sayısı, değişken sayısının en az iki katı olmalidir (Bouss ofianee vd.,1991).

Değişken sayısının belirlenmesinden sonra etkin üretim sınırının çiziminde aşağıdaki adımlar izlenmektedir;

- Yatay eksene paralel olarak alınan bir doğru, ilk gözleme temas edene kadar yukarı kaydırılır,

- Gözleme temas edildiğinde, gözlem pivot noktası olacak şekilde, doğrunun sol tarafi saat yönünde çevrilir,

- Çevirme işlemi yeni bir gözleme temas edilene veya doğrunun sol tarafi düşey eksene paralel olana kadar sürer,

- Doğrunun sol tarafi düşey eks ene paralel olduğunda iş lem sona erer, yoksa ikinci adıma dönülür.

$\mathrm{Bu}$ adımlar sayesinde, tüm gözlemlerin etkin sınır tarafından zarflanması sağ lanmış olmaktadır ve bu sınırın dışında hiç bir gözlem kalmamaktadır. Zarfin içinde kalan tüm gözlemler, zarf üzerinde bulunan gözlemlerin doğrusal kombinasyonlarıyla yaratılabilecek hipotetik gözlemlerden daha düşük performans göstermiştir olacaktır (Tarım, 2001). 
Çizelge 1. Etkinlik ölçüm yöntemleri

\begin{tabular}{llll}
\hline Yöntemler & & & \\
\hline Karşılaştırma ölçütleri & Oran analizi & Parametrik yöntemler & Parametrik olmayan yöntemler \\
\hline Çözüm tekniği & Oranlamalar & Regresyon & Matematiksel programlama \\
İçerik & Tek girdi/Tek çıktı & Çok girdi/Tek çıktı & Çok girdi/Çok çıktı \\
Ön hazırlık & Basit & Basit & Detaylı \\
Uygulama & Kolay & Kolay & Detaylı \\
Performans ölçümüne uygunluğu & Kisitlı & Kisitlı & Geniş \\
\hline
\end{tabular}

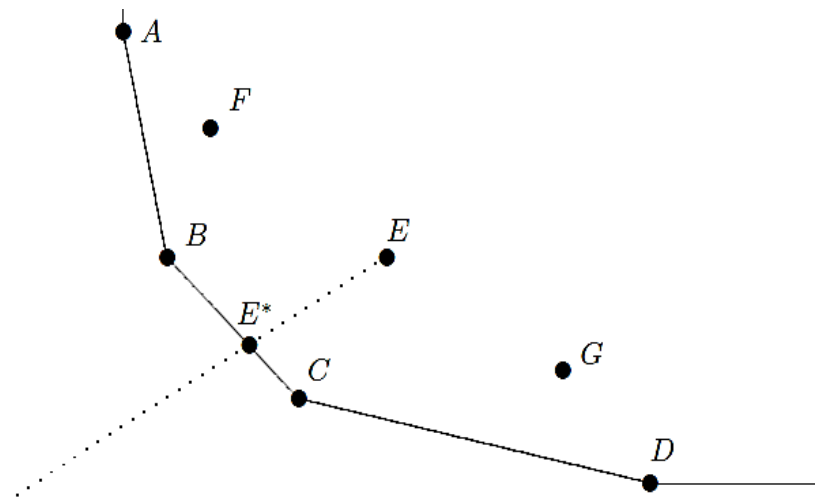

Şekil 1. Etkinlik Sinırı

Şekil 1.'de etkin sınır üzerinde yer alan A, B, C, D gözlemler ile zarf içinde yer alan E, F, G gözlemleri gösterilmektedir. Etkinlik değeri $0.0-1.0$ aralığındadır. Etkin üretim sınırı üzerindeki gözlemlerin $(\mathrm{A}, \mathrm{B}, \mathrm{C}, \mathrm{D})$ etkinlik değeri 1.0 ve bu gözlemler etkindir. Zarf içinde kalan gözlemler (D, E, F) kendilerine bir rol model seçerek etkinlik sınırı üzerinde yer almaya çalışmaktadırlar. Şekilde etkin olmayan E gözlemi etkinlik sınırı üzerinde tanımlanan $E^{*}$ 'yi kendine rol model seçerek kendini etkin duruma getirmeye çalışacaktır.

VZA doğrusal programlama yönteminin geliştirilmiş bir biçimi olduğu için tüm doğrusal programlama modelleri için geçerli özellikler VZA için de geçerlidir. VZA modellerinde de sinırlayıcı kısıtlar altında, amaç fonksiyonu maksimizasyon ya da minimizasyon şeklindedir. Sinırlı kaynakların etkin kullanımı istendiğinden doğrusal programlama için geçerli olan;

Kesinlik: Modelin tüm katsayılarının kes inlikle bilindiği

Orantı: Hem amaç fonksiyonunda hem de kısıtlarda bir orantı olduğu

Toplanabilirlik: Tüm ürünlerin birbirinden bağımsız olduğu

Bölünebilirlik: Çözüm değerlerinin tam sayı olmasının gerekmediği

Negatif olmama: Tüm değişkenlerin sıfır ya da pozitif olduğu varsayımları VZA modelleri içinde geçerlidir (Oruç, 2008).

VZA'nın uygulanabilmesi için gerekli olan aşamalar aşağıdaki şekilde s rralanmaktadır.

1- Karar verme birimlerinin belirlenmesi,

2- Girdi ve çıktı kümelerinin belirlenmesi,

3-VZA ile göreli etkinlik ölçümü,

4- Her karar birimi için detay analizi ve

5- Sonuçların değerlendirilmesidir.

VZA modelinde, bir KVB' nin etkin olması için iki şart bulunmaktadır ve bu şartlara uyan KVB'lerin etkinlik skoru 1'e eşittir. Etkinsiz bir karar birimin performans1, bu
KVB'lerin oluşturduğu etkinlik sınırına olan uzaklıkla belirlenir.

$\mathrm{Bu}$ şartlar;

1.Hiçbir çıktının değeri, bir ya da daha fazla girdinin değeri artırılmadan veya bir ya da daha fazla çıktının değeri azalmadan arttırilamaz.

2. Hiçbir girdinin değeri, bir ya da daha fazla girdinin değeri artırılmadan veya bir ya da daha fazla çıtının değeri azalmadan düşürülemez şeklindedir (Özyiğit ve ark., 2008).

VZA'da, zarflama şekli ve etkin olmayan birimlerin etkin üretim sınırına olan uzaklıklarına göre farklı modeller tanımlanmıştır (Paradi ve Schaffnit, 2004).

Zarflama şekli ile ilgili olarak:

1.1978 yılında Charnes, Cooper ve Rhodes (CCR) tarafindan Ölçeğe Göre Sabit Getiri (girdilerin bileşim oranı değiştirilmeden kullanılan girdiler $£$ kat artırıldığında, çıtıların da $£$ kat arttığ 1 Constant Return to Scale (CRS) varsayımı altında,

2.1984 yllında Banker, Charnes ve Cooper(BCC) tarafindan Ölçeğe Göre Değişken Getiri (girdilerin bileşim oran1 değiştirilmeden kullanılan girdiler $£$ kat artırıldığında, çıktıların £'dan farklı oranda arttığ 1 Variable Return to Scale-VRS) varsayımı altında modeller tanımlanmıştır.

Etkin olmayan birimlerin etkin üretim sinırına olan uzaklıklarına göre de:

1. Girdiye yönelik (Çıktı seviyesini değiştirmeden, bu çıktı düzeyini en etkin şekilde elde etmek için girdi bileşiminin ne kadar azaltılması gerektiğini araştıran model)

2. Çıktıya yönelik (Girdi seviyes ini değiştirmeden, bu girdi düzeyi ile işletmeyi etkin hale getirebilmek için çiktı bileşiminin ne kadar artırılması gerektiğini araştıran model) VZA modelleri tanımlanmıştır.

BCC modeline ölçeğe göre değişken getiri varsayımı altında elde edilen etkinlik değerleri, CCR modeli ölçeğe göre sabit getiri varsayımı altında elde edilen etkinlik değerlerine eşit ya da daha büyük değerler vermektedir (Delikdaş, 2002).

Çalışmada kapsamında Girdiye Yönelik CCR Modeli açıklanmıştır.

\subsection{Girdiye yönelik CCR modeli}

Ölçeğe göre sabit getiri varsayımını temel alan bu yöntem çıktı seviyesini değiştirmeden, en etkin şekilde bu çıktı düzeyini elde etmek için, girdi bileşiminin ne kadar azaltılmas1 gerektiğini araştıran model olarak tanımlamaktadır. Temelde kesirli programlama olan bu model aşağıdaki gibidir ve bu bölümün oluşturulmasında 
(Onaran, 2006; Oruç, 2008; Yaşa, 2008; Deniz, 2009; Kecek, 2010)'dan yararlanılmıştır.

Girdiye yönelik kesirli programlama modeli aşağıdaki şekilde kurulmaktadır.

İncelenen sistemde, s tane çıtı faktörü, $m$ tane girdi faktörü kullanılarak üretilmektedir. Her biri bir gözlem olan $\mathrm{N}$ tane karar birimi içinden karar birimi k'nın, $\mathrm{k}=1, \ldots \ldots, \mathrm{N}$, kullandığ 1 girdi i, $\mathrm{i}=1, \ldots \ldots \ldots . \mathrm{m}$, miktarı Xik ve ürettiği çıkt1 miktarı $\mathrm{r}, \mathrm{r}=1, \ldots \ldots \ldots . . \mathrm{s}$, miktarı Yrk , $x_{i j}$ : $j$. karar biriminin kullandığı i. girdi miktarı, $y_{r j}$ : $j$. karar biriminin kullandığ 1 r. çıktı miktarı, olarak tanımlanmıştır.

Model

$$
E_{0}=\max \frac{\sum_{r=1}^{s} u_{r k} y_{r k}}{\sum_{i=1}^{m} v_{i k} x_{i k}}
$$

st.

$$
\frac{\sum_{r=1}^{s} u_{r k} y_{r j}}{\sum_{i=1}^{m} v_{i k} x_{i j}} \leq 1
$$

$$
j=1, \ldots \ldots . N
$$

$u_{r k} \geq \in, v_{i k} \geq \in$

$$
r=1, \ldots \ldots . s, i=1, \ldots \ldots . m
$$

$\in$ :Yeterince küçük pozitif bir sayıyı (0,0000001) göstermektedir.

Etkinlik değerlerinin hesaplanmasında kesirli programlama modeli kullanılmamaktadır. Bunun nedeni girdi ve çıktı sayılarının fazla olduğu durumlarda modelin çözümünün oldukça güç olmasıdır. Kesirli programlama modelinin çözümündeki güçlükleri ortadan kaldırmak amaciyla Charnes, Cooper ve Rhodes tarafindan 1978 yılında kesirli programlama modelini, doğrusal programlama modeline dönüştürebilmek için bir trans formasyon kullanmış lardır (Çekin,1999).

Dönüşüm işlemi, amaç fonksiyonun paydası normalize edilip 1'e eşitlenerek, doğrusal programlama modelinde $\sum_{i=1}^{m} v_{i k} x_{i k}=1$ ş eklinde kıs ıtların olduğu yere yerleş tirilmiştir. Eşitlik (1)' de verilen doğrusal programlama modelinin kısıtının her iki tarafi payda ile çarpılarak yeni kısıt elde edilmiştir. Çarpan modeli (MI) olarak da adlandırılan bu model simplex algoritması yardımıyla kolaylıkla çözülebilir (Tarım, 2001; Charnes ve ark.,1981):

Model (MI)

$\max$

$$
\theta_{k}=\sum_{r=1}^{s} u_{r k} y_{r k}
$$

st.

$$
\begin{aligned}
& \sum_{i=1}^{m} v_{i k} x_{i k}=1 \\
& \sum_{r=1}^{s} u_{r k} y_{r j}-\sum_{i=1}^{m} v_{i k} x_{i j} \leq 0 \\
& j=1, \ldots \ldots . N \\
& u_{r k} \geq 0, v_{i k} \geq 0 \quad r=1, \ldots \ldots . s, i=1, \ldots \ldots . m
\end{aligned}
$$

Eşitlik 2 ile verilen modelin çözümü sonucunda, etkinliği ölçülen $k$ karar birimi için $\theta^{*}=1, v_{i k}{ }^{*}>0$ ve $u_{r k}{ }^{*}>0$ olmak üzere en az bir $v^{*}, u^{*}$ optimal çözümü varsa KVB etkindir. Diğer durumlarda ise KVB etkin değildir. Etkin olmayan KVB için $j \in\{1,2, \ldots ., N\}$ ve $E_{k}=\left\{j: \sum_{r=1}^{s} u_{r k}{ }^{*} y_{r j}=\sum_{i=1}^{m} v_{i k}{ }^{*} x_{i j}\right\}$ olacak şekilde bir $E_{k}$ kümesi tanımlanırsa, bu küme karar birimi $k$ için referans kümesini oluşturacaktır. Bu küme aynı zamanda etkinlik sınırını oluşturan kümenin de bir alt kümesidir. Her ne kadar bulunan ağırlık değerleri karar birimi $k$ için seçilmiş olsalar da başka karar birimleri için bu ağırlıklar daha uygun olabilmekte ve kısıtın her iki tarafinı eşitleyerek etkinlik değerini 1.0 yapabilmektedir. İşte bu tip karar birimleri sınır üzerinde yer alarak $k$ karar birimi için referans kümesini yada diğer bir deyişle rol modellerini tanımlarlar. Bu durumda etkin olmayan karar birimi $k$, girdilerini belirli bir oranda azaltarak kendisine referans olan bu karar birimlerinin doğrusal kombinasyonları sonucunda oluşan ve etkin olan hipotetik karar birimine benzemeye çalışacaktır (Kaynar, 2004).

Her doğrusal programlama probleminin ilişkili olduğu bir ikiz problemi vardır. Herhangibir doğrusal programlama problemi primal olarak isimlendirilirken ikizine dual adı verilir. Primal ve dual problemlerin optimal çözüm değerleri birbirinin aynısıdır. Bazı doğrusal programlama modellerinde bazen primal model yerine dual modeli kullanmak daha az hesaplama gerektirir (Öztürk, 2007) Çarpan modeli olarak eşitlik 2'de verilen modelin dual formu, kısıt sayısının daha az olması ve yönetsel açıdan önemli bilgiler içermesi nedeniyle incelenmesi ve üzerinde durulmas1 gerekmektedir. Zarflama modeli olarak da adlandırılan bu model aşağıda verilmiştir.

Model

$\min \theta_{k}$

st.

$$
\begin{aligned}
& \theta x_{i k}-\sum_{j=1}^{N} x_{i j} \lambda_{j k}-s_{i k}^{-}=0 \\
& i=1, \ldots \ldots . m \\
& \sum_{j=1}^{N} y_{r j} \lambda_{j k}=y_{r k}+s_{r k}^{+} \\
& r=1, \ldots \ldots . s \\
& s_{i k}{ }^{-*}, s_{r k}{ }^{+*}, \lambda_{j k} \geq 0, \theta \text { kisits 1z } \\
& j=1, \ldots \ldots . . N
\end{aligned}
$$

$\theta$ etkinlik skorunu gösterirken $\lambda_{j k}$ değişkeni ise referans kümenin belirlenmesinde kullanılır. $\lambda_{j k} \geq 0$ olan karar birimleri etkin olarak değerlendirilir. $\mathrm{Bu}$ karar birimleri, etkin olmayanlar karar birimleri için referans kümesini oluştururlar. Genellikle, eğer $\mathrm{k}$ etkin ise, dual değişken, $\lambda_{k k}$ 'nın değeri de 1'e eşit olacaktır o zaman 
referans kümesindeki tek karar birimi kendisi bulunacaktır. Modelde yer alan $s_{i k}{ }^{-}$ve $s_{r k}{ }^{+}$değişkenleri ise, sırasıyla girdilerdeki fazlalığı ve çıktılardaki eksikliği gösteren aylak değiş kenlerdir (Tarım, 2001).

\section{Ormancilıkta VZA uygulamaları}

Son yıllarda dünyada ve Türkiye'de çağdaş devlet anlayış̧ında meydana gelen değişmenin bir sonucu olarak ekonomide kamu sektörünün payının azaltılması, piyasa ekonomisine işlerlik kazandırılması ve üretim faktörlerinin verimli ve etkin kullanılması görüşü önem kazanmaya başlamıştır. $\mathrm{Bu}$ kapsamda bir kamu malı niteliğindeki ormanların da etkin ve verimli bir şekilde iş letilmesi önem kazanmıştır. Etkinlik ölçümünde parametrik ve parametrik olmayan yöntemler mevcut olmakla birlikte, en çok tercih edilen yöntem VZA'dır. VZA, işletmelerin performansı ölçebilmek için geliştirilmiş olan doğrusal programlama tabanlı ve parametrik olmayan bir yöntemdir. Literatürde orman kaynaklarının etkin kullanımının VZA ile ölçülmesi üzerine çalışmaların yanında özellikle Devlet Orman İşletmelerinin başarı düzeylerinin ölçülmesi üzerine çalışmalar bulunmaktadır.

Kao ve Yang (1991)'de ormanların sağlamış olduğu hizmetlerin birçoğunun piyasa değerinin belirlenememes inden dolayı, ormanların çok amaçlı ve etkin bir şekilde yönetmenin güç olduğu vurgulanmıştır. Çalışmalarında 1978-1987 yıllarına ait verilerin ortalaması alınarak 10 yıllık dönemde 13 doğal orman bölgesinin teknik etkinliği ölçülmüştür. Çalışmada dört girdi ve dört çıktı değişken kullanılmıştır. Kullanılan çıktı değişkenleri; hektardaki odun üretimmiktarı, hektar başına üretilen odun dışı orman ürünlerinin parasal değeri, toprak koruma ve hektardaki yıllık ziyaretçi sayısı olup; girdi değişkenler ise hektar başına yıllık bütçe, başlangıç yılında hektardaki servet miktarı, hektarda kullanılan işgücü sayısı ve arazi büyüklüğüdür.

Carter ve Cubbage (1995)'de 1979 ve 1987 yıllarında Güney Amerika'da 12 eyalette kâğıtlık odun üreten firmaların stokastik sınır yaklaşımı (SFA) ile teknik etkinliğini ölçmüşlerdir. Çalışmada girdi olarak sermaye, işgücü miktarı, fabrika sahibinin yaşı ve hasat tipi (ibreli, yapraklı, karışık); çıktı olarak da haftalık ortalama toplam üretim miktarı dikkate alınmıştır.

Hs eu ve Buongiorno (1995)'de Kanada ve Amerika'daki kâğıt hamuru ve kâğıt endüstrisindeki teknoloji ve üretici davranışlarını deterministik ve stokastik testlerle araştırmıştır. Çalışmada dört çıktı değişken olarak; kâğ ıt hamuru, gazete kâğıd1, gazeteden küçük kâğıtlar, afiş kâğıdı ve dokuz girdi değişkeni olarak da sermaye, üretimde çalışan işgücü miktarı, üretim dışında çalışan işgücü miktarı, enerji miktarı, kimyasallar, atık kâğıtlar, odun hamuru, kâğıtlık odun ve diğger materyaller kullanılmıştır.

Shiba (1997)'de veri zarflama analiziyle ormancilik faaliyetlerindeki yönetsel ve teknik performans etkinliğini ölçmüştür. Çalışma Japonya'daki 28 adet orman sahipleri birliğine ait 1991-1994 yılları arasındaki finansal verilerin ortalamasına dayanmaktadır. Üç farklı etkinlik modelinde 16 adet girdi ve 3 adet çıktı olmak üzere toplam 19 değiş ken kullanılmıştır. Çalışmada kullanılan girdiler; toplam orman sahipleri birliği üye sayısı, toplam çalışan sayısı, 50 hektar ve üzerinde orman sahibi sayıs1, toplam devamlı orman işçisi sayıs1, toplam yatırım gideri, birliğ in yetki alanındaki ormanllk alan, toplam maliyet, aktifler toplamı, üretimde kullanılan makine sayıs1, $50 \mathrm{kw}$ üstündeki kereste makinesi, toplam depo alan1, toplam odun üretimi, toplam ormanlaştırilan alan, toplam açılan alan ve toplam tomruk üretimidir. Çıktılar ise; toplam hasılat, toplam net kar ve orman sahipleri birliğindeki toplam çalışan sayısıdır.

Yin (1998)'de 5 tanesi Kanada' da olmak üzere Kuzey Amerika'da ki toplam 44 adet oluklu mukavva üreticisinin VZA ile teknik, ölçek ve tahsis etkinliğini ölçmüştür. Analizde 7 girdi ve 1 çıktı olmak üzere toplam 8 adet değişken kullanılmıştır. Çalışmada girdi değiş kenleri olarak üretimde bir birimde kullanılan fiber, yakıt, elektrik gücü, işgücü, ücret, hammadde ve kimyasallar kullanılırken, çıktı değişkeni olarak ise yıllık toplam üretim miktarı değerlendirilmiştir.

Viitala ve Hanninen (1998)'de Finlandiya'da 19 bölges el ormancıllk kuruluşunun etkinliği VZA kullanılarak araştırılmıştır. Çalışmada, 1 girdi ve 15 çıktı değişkeni kullanılmıştır. Tek girdi değişkeni olarak toplam maliyet kullanılırken, çıktı olarak toplam 6 grupta (planlanan ve kontrol edilen yol miktarı, planlanan ve denetlenen drenaj uzunluğu, hazırlanan orman yönetim planı, eğitim ve yayım faaliyetleri, orman kanunlarının uygulamasının denetimi, orman ıslahının yönetimsel sorunlarının ele alınmas1) toplanan planlanan orman yolu miktarı, denetimi yapılan orman yolu inşaatı, incelenen ve onaylanan orman yolu, planlanan drenaj uzunluğu, denetimi yapılımış drenaj uzunluğu, incelenen ve onaylanan drenaj uzunluğu, planlanan bölgesel orman yönetimi alan olarak, ev yapımında ve yakıt olarak kullanılacak ağaç yetiş tirmek için orman planlarında ayrılan yer sayıs1, orman sahiplerinin yüz yüze istedikleri yardım sayısı, grup çalışmalarına katılan orman sahibisayıs1, orman kurullarının personeline verdiği kursların toplam gün sayısı, onaylanmış orman ıslah proje sayısı ve onaylanmış yenileme proje sayısı değişkenleri kullanılmıştır. Çalışma sonucunda potansiyel girdilerde \% 20 oranında tasarruf sağlanması ile ormancılık kurumlarının etkinliğinin önemli ölçüde değişeceği ifade edilmiştir.

Kao (1998)'de çoklu çalışma serileriyle ormanların etkinlik ölçümü çalışması Taiwan'da 8 ormanlık bölgede ve 34 çoklu çalışma serisinde gerçekleştirilmiştir. Çalışmada VZA'da 4 girdi ve 3 çıktı olmak üzere toplam 7 değişken kullanılmıştır. Çıktı değişkenleri olarak; yıllık odun üretim miktarı, toprak koruma ve rekreasyon, girdi değişkenleri olarak; alan, pers onel sayısı, mas raflar ve periyot başındaki stok miktarı kullanılmıştır. Analiz sonucunda araștırma bölgesindeki ormanlık alanların performansları ve bu performans ları karşılaştırılmış tır.

Lebel ve Stuart (1998)'de VZA tekniği ile 1988-1994 yılları aras ında kereste üretimi iş lerinde çalışan 23 firmadaki 109 işçinin teknik etkinlikleri değerlendirilmiş tir. Çalışmada üretilen odun miktarı çıktı değişkeni; sermaye, sarf malzeme giderleri ve emek ücreti ise girdi değişkenleri olarak kullanılmıştır. Çalışma sonucunda 1988-1994 yılları arasında kereste üretiminde çalışanların etkin çalış tığ 1 ancak bazılarının diğerlerine göre oldukça düşük etkinliğe sahip olduğu belirlenmiştir. Düşük kapasite kullanımının teknik etkinlik üzerine olumsuz etkisi olduğu ortaya konularak işlem hacminin teknik etkinlik üzerinde etkili olduğu sonucuna varılmıştır. En iyi işlem hacminin yıllık 75.000 ton olduğu hesaplanmıştır.

Joro ve Viitala (1999)'da etkinlik modelleri üzerindeki eleştirileri birleştirmek ve bunların devlet ormancıllk 
organizasyonunun etkinlik değerleri üzerindeki etkisini araştırmak amacıyla VZA tekniği için üç farklı uzantı geliştirmişlerdir. Uzantılar, birimlerin doğru işler yapıp yapmadığını, yani onların girdi ve çıktı kombinas yonlarının bazı kârlılık kriterlerine göre optimal olup olmadığını değerlendirmektedir. Çalışma 19 ormancıllk kurulunda gerçekleştirilmiş olup 1998'de Viitala ve Hanninen kullanmış oldukları bir girdi ve 15 çıktı değişkeni kullanılmıştır. Ancak çalışmada kullanılan modelde tüm çıktıların yer alması durumunda 19 ormancılık kurumunun bir tanesi hariç hepsi etkin çıkmıştır. Bu sebepten dolayı ormanlardaki altı aktiviteyi içeren farklı modeller oluşturularak alternatif yaklaşımlar geliştirilmiş ve her model iki veya üç çıtı değişkeni içerecek şekilde düzenlenmiștir.

Kao (2000a)'da Tayvan'da bir orman bölgesindeki 34 çalışma birimindeki bitkilerin, kısa ve uzun dönemdeki etkinlikleri VZA tekniği ile karşılaştırılmıştır. Çalışmada arazi büyüklügü, işgücü miktarı, yıllık harcamalar toplamı ve periyot başındaki servet miktarı girdi değișken; yıllık odun üretim miktarı, ortalama hacim, ziyaretçi sayısı çıktı değişken olarak alınmıştır. Teorik olarak daima her bir bitkinin uzun dönem etkinlik değerleri, kısa dönem etkinlik değerlerinden küçük veya eşittir. Ancak; burada karar vericilerin kısa ve uzun dönemdeki başarılarının bitkiler üzerinden karşılaştırılabileceği vurgulanmaktadır.

Kao (2000b)'de yeniden yapilandırilan Taiwan Ormanlarının performans gelişimini ölçmede 4 girdi ve 3 çıktı değişkeni kullanmıştır. Girdi değișkeni olarak alan, personel sayıs1, yıllık harcama ve servet kullanılırken; çıkt1 değişkeni olarak üretim miktarı, servet ve yıllık ziyaretçi sayısı kullanılmıştır. Çıktı değişkeni olarak kullanılan servet, toprak muhafaza değerini temsil etmektedir. Diğer bir çıktı değişkeni olarak ormanların rekreasyon değeri kullanılmış ve bu değişken çıktılarda yıllık ziyaretçi sayıs 1 olarak değerlendirilmiştir.

Kao (2000c)'de Tayvan'da 1989 ve 1992 yıllarındaki sekiz doğal orman bölgesinin etkinlik değerlerindeki değişim, VZA ve Malmquist Toplam Faktör Verimliliği (TFV) indeksi ile çözümlenmiştir. Çalışmada, 3 üç çıktı ve 4dört girdi değişkenden yararlanılmıştır. Kullanılan çıktı değişkenler, hektardaki odun üretim miktarı, toprak koruma, hektardaki yıllık ziyaretçi sayısı olup, girdi değiş kenler arazi büyüklüğü, hektarda kullanılan iş gücü sayısı, yıllık masraflar, servet miktarıdır. Araştırmada, Malmquist TFV indeksinin daha kullanış lı olduğu belirtilmektedir.

Bogetoft ve arkadaşları (2001)'de Danimarka Ormancıllk Servisine bağlı 14 bölge ofisinin 1997- 1999 yılları arasındaki etkinliğini VZA yöntemiyle ölçülmüştür. Çalışmada yöntem giderleri tek girdi olarak kullanılırken her ofisin yıllık sermaye fazlalığı, bölge ofislerinin üyelerine yarattığ 1 sermaye fazlalı̆̆1 ve bölge ofisinin üyelerine yıllık fide satış1 çıktı değişkeni olarak kullanılmıştır.

Zhang (2002)'de Çin'in Heilongjiang Bölgesindeki 40 devlet ormanında silvikültürel aktivitelerin etkinliği, reform öncesi (1985-87) ve reform sonrası (1995-97) geçiş dönemi, girdi yönelimli VZA tekniği ile karşılaştırılmıştır. Silvikültürel etkinlikler için ağaçlandırma alanı, orman içi ağaçlandırma alanı, genç orman bakımı temel çıktı değişkenleri olarak seçilmiştir. Çalışmada, toplam maliyetler girdi değişken olarak ele alınmıştır.
Nyrud ve Bergseng (2002) Norveç'teki kereste fabrikalarının üretim etkinliği ve büyüklüğü üzerine yapmış oldukları çalışmada etkinliği ölçmek için VZA yöntemini kullanırken; etkinlik değerleriyle büyüklüğü ilişkilendirmede ise sansürlü regresyon analizi ve parametrik olmayan testlerden yararlanılmıştır. Çalışmada 1974-1991 yılları arasındaki fabrika verilerinden yararlanılmıştır. Tomruk girişinin girdi ve üretilen kerestenin çıktı olarak kullanıldığı çalışmada ortalama etkinliklere bakıldığında düşük kapasiteli kereste fabrikalarının etkinliklerinin düșük olduğu sonucuna varılmıștır.

Strange (2003)'de Danimarka'da, biyolojik çeşitlilik için önerilen rezerv alanının etkinliğini belirlemek amacıyla VZA tekniği kullanılmıștır. Çalışmada biyolojik çeșitlilik, maliyet ve korumaya yönelik verilerinden yararlanılmıştır. Tarım arazilerinin satın alınması maliyeti ve koruma çatışma değeri girdi değişken, tür sayısı, koruma firsat değeri ile rekreasyonel amaçlı kullanımın erişilebilirlik değeri de çıktı değiş ken olarak kullanılmıştır.

Alım (2004)'de 1994-2002 yilları arasındaki Türkiye'deki 27 Orman Bölge Müdürlügünün etkinliğini VZA ile ölçülmüștür ve ölçeğe göre değiș en getiri yaklaşımı girdi yönelimli CCR modeli kullanılmıș tır. Çalışmada, genel üretim giderleri, araştırma ve geliştirme giderleri, genel yönetimgiderleri, alan ve personel sayısı de ğişkenleri girdi değişken, kereste üretimi ve yan ürünlerin parasal değeri de çıktı değişken olarak kullanılmıştır.

Liu ve Yin (2004)'de 1978-1997 y1llarında 93 kırsal hanenin verimliliğini ölçmek amacıyla, VZA tekniğinden yararlanılmıştır. Çalışmada, tahıl üretiminde kullanılan arazi büyüklüğü, orman arazisi büyüklüğü, tahıl üretimindeki masraflar, ormanc1lıktaki masraflar, hayvan üretimi masrafları ve diğer masraflar girdi değişken, yine tahıl üretim değeri, orman ürünleri değeri, hayvan üretim değeri ve diğer üretim değerleri de çıktı değişken olarak kullanılmış tir.

Illukpitiya (2005)'de Sri Lanka'da orman sinırlarındaki çiftçilik aktivitelerinin teknik etkinliğini değerlendirerek çiftçilerin verimlilik ve etkinliğini etkileyen faktörleri tanımlamıştır. Ayrıca orman ürünlerinin ekonomik değerini ve odun dışı orman ürünlerinin kırsal ekonomiye katkısını da ortaya koymaya çalışmışır. Çalışmada, tarımsal arazi büyüklüğü, ailenin mevcut işgücü varlığı, kiralanan işgücü miktarı, kullanılan suni gübre miktarı, kullanılan doğal gübre miktarı, kullanılan böcek ilacı miktarı ve diğer girdiler ile çiftçi yaş1, çiftçi deneyimi, çiftçi eğitim seviyesi, çiftçinin günlük aldığı kalori miktarı, cinsiyet, yayım gibi sosyo-ekonomik değișkenler girdi kullanılmıștır.

Balteiro ve arkadaşları (2006)'da İspanya'nın odun kökenli endüstrisinin üretim verimliliği ve yenilenme faaliyetleri ile arasındaki ilișkiler analiz edilmiștir. Çalışmada, VZA ve logistik regresyon modelinden yararlanılmıştır. VZA tekniğinde girdi değişkenleri olarak işçi sayısı, fonlar, borçlar ve çıktı değişkenler olarak da ücret ve kar kullanılmıștır.

Lien ve arkadaşları (2006)'da özel orman sahiplerinin orman mülkiyeti ve sahiplik karakteristiklerindeki önemli faktörlerin verimlilik üzerindeki etkisini, SFA ile değerlendirilmiştir. Girdi değişken olarak iş gücü miktarı, orman kesim alanı ve sermaye değeri (maksimum sürdürülebilir hâsılatın parasal değeri) dikkate alınmıștır. Çıktı değişken olarak odun hammaddesi üretim miktarı 
kullanılmıştır. Çalışmada ayrıca sekiz dışsal değişkenden de (orman sahibinin yaşı, üretimyapılan alandan amaç dışında elde edilen gelirler, tarımsal gelir, maaş geliri, borçlar, yönetim planının olup olmaması, eğitim seviyesi, alanın kente yakın olup olmamas1) yararlanılmıştır.

Sauer ve Abdallah (2007)'de Miombo Ormanları civarındaki beş köyde tütün üretiminin etkinliği, biyolojik çeşitlilik ve orman kaynaklanı yönetimi arasındaki ilişki VZA ile incelenmiştir. İlk olarak orman alanları sınırındaki tütün üretiminin etkinliği, ikinci adımda ise orman alanlarındaki biyolojik çeşitlilik, arazi verimliliği, eğitim seviyesi, tütün üretiminin etkinliği, kullanılan arazinin kalitesi, üretilen çıktıların kalitesi ve orman yönetimi açısından kurumsal düzenlemeler analiz edilmiştir. Girdi değişkenler olarak; toplam tütün üretim miktarı, yakacak odun miktarı, işgücü miktarı, arazi miktarı, kullanılan gübre miktarı ve çıktı değişkenleri olarak da; işgücü ücreti, yakacak odun fiyatı, gübre fiyatı, tarımsal arazi fiyat1, toplam tütün üretimi maliyeti, tür çeşitliliği indeksi, kullanılan arazi tipi, çiftçi deneyimi, tütün üretiminde kullanılan teknoloji, çiftçi eğitim yılı, tarım arazilerinin merkeze uzaklığı, orman sınırının tarım arazilerine olan uzaklığı, üretim miktarı ve kurumsal düzenlemeler kullanılmıştır.

Başar ve ark. (2009)'da Türkiye'de döner sermaye işletmeleri olan Devlet Orman İşletmelerinin (DOİ) etkinlik düzeylerini SFA ile tespit etmiştir. Bu kapsamda çalışma yılında Türkiye'de faaliyet gösteren 217 DOİ'nin etkinlik düzeylerini belirleme 4 girdi ve 1 çıktı değişkeni kullanmıştır. Girdi değişkenleri olarak servet, toplam verimli orman alanı, toplam çalışan sayısı ve üretim faaliyetine katılan köylü sayısı kullanılmıştır. Çıkt1 değişkeni olarak işletmenin bir yıl içinde yaptığ 1 orman ürünleri satışlarının TL değeri kullanılmıştır.

Kao (2009)'da paralel üretim sistemlerinde etkinlik ölçümü çalışmasında Taiwan Ormanları verilerini kullanmıştır. Çalışmada 4 girdi ve 3 çıktı değişkeni kullanmıştır. Girdi değişkeni olarak alan, personel sayısı, yıllık harcama ve servet kullanılırken, çıktı değiş keni olarak üretim miktarı, servet ve yıllık ziyaretçi sayıs 1 kullanılmıştır. Çıktı değişkeniolarak toprak muhafaza değeri kullanılmıştır yüksek servet miktarının toprak erozyonunu azaltıcı etkisi olduğu varsayımından bu değişken çıktılarda servet miktarı olarak değerlendirilmiştir. Diğer bir çıktı değişkeni olarak ormanların rekreasyon değeri kullanılmış ve bu değişken çıktılarda yıllık ziyaretçi sayısı olarak değerlendirilmiştir.

Şafak (2009)'da Ege Bölgesindeki Devlet Orman İşletmelerinin etkinlik düzeyleri toplam 26 devlet orman işletme müdürlüğünün 2005-2007 yıllarına ait faaliyetleri esas alınarak klasik ve bulanık VZA teknikleri ile değerlendirilmiştir. Çalışmada 9 girdi ve 7 çıktı değişkeni kullanılmıştır. girdi değişkenleri işletmenin toplam alanı, orman alanı, toplam ağaç serveti, planlanmış toplam üretim miktarı, toplam personel sayısı, iş letme sorumluluk alanı nüfusu, toplam orman yangını gideri, üretilen toplam odun miktarı, giderler genel toplamı, çıktı değişkenleri olarak da yol yoğunluğu, silvikültür çalışması yapılan alan miktarı, toplamodun satış miktarı, brüt satış lar toplamı, dönem karı, dönen varlıklar toplamı, duran varlıklar toplamı kullanılmıştır.
Korkmaz (2011)'de Akdeniz Bölgesi'nde ki 37 adet Devlet Orman İşletmesinin üretim etkinliğinin VZA yardımıyla ölçülmesi çalışmasında 8 girdi ve 4 çıktı değișkeni kullanılmıștır. Girdi olarak sermaye, toplam alan, ormanlık alan, verimli orman alanı, üretim maliyetleri, çalışan giderleri, teknik eleman miktarı ve toplam çalışan sayıs1 ; çıktı olarak ise üretim miktarı, satış gelirleri, satış miktarı ve katma değer kullanılmıştır.

Kara ve arkadaşları (2013) toplam 4 Devlet Orman İşletmesinin üretim, finansal ve servet artışı etkinliklerini analiz etmek amacıyla toplam 6 girdi ve 3 çıtı değişkenin kullanıldığ1 3 model kurgulamışlardır. Modellerde girdi değişkenleri olarak dikili kabuk gövde hacmi, personel sayısı, verimli orman alanı, dikili ağaç satışları, döner sermaye toplam gideri ve silvikültür çalışma alanı, çıktı değişkenleri olarak da üretim miktarı, dönem karı/zararı ve toplam dikili ağaç serveti kullanılmıştır.

Bayramoğlu (2013) Doğu Karadeniz Bölgesi’nde 20052010 yılları arasında faaliyet gösteren 24 DOİ'nin etkinlik düzeylerini 5 girdi 3 çıktı kullanarak VZA ile tespit etmiştir. Çalışmada oluşturulan amaç fonksiyonunda girdi değişkenleri olarak; DOİ Genel Alanı, DOİ Serveti, DOİ Genel Alanı İçindeki Nüfus, DOİ Personel Sayısı ve DOİ Toplam Giderleri kullanılmıştır. Çıktı değişkenleri olarak ise DOİ Üretim Miktarı, DOİ Satış Miktarı ve DOİ Toplam Geliri kullanılmıştır.

Şafak vd. (2012) Denizli, İzmir ve Muğla Orman Bölge Müdürlüğü bünyesindeki Orman İşletme Şefliklerinin etkinliğini bulanı veri zarflama yöntemi ile belirlemişlerdir. Çalışmada Denizli Orman Bölge Müdürlüğü için 23 girdi 18 çıtı, İzmir Orman Bölge Müdürlüğü için 27 girdi 23 çıktı ve Muğla Orman Bölge Müdürlüğü için 33 girdi 21 çıktı ve Ege Bölgesi için oluşturulan amaç fonksiyonunda 36 girdi 21 çıktı değişkeni kullanmış lardır.

Şafak vd. (2013) İzmir Orman Bölge Müdürlüğünde bulanık veri zarflama analizi kullanarak toplam 7 girdi 7 çıktı değişkeniyle etkinlik ölçümü yapmışlardır. Çalışmada amaç fonksiyonunda girdi değişkenleri olarak; Ormanlık alanda yaşayan nüfus, toplam silvikültür harcamaları, genel üretim giderleri, toplam çalışan sayısı, ormanlık alan, yıllık izin verilen kesim alanı ve toplam yangın söndürme aracı sayısı kullanılmıştır. Çıktı değiş kenleri olarak toplam orman yolu uzunluğu, endüstriyel odun üretim miktarı, yıllık dikili satış miktarı, resmi orman suçu sayısı, yanan alan miktarı, silvikültürel müdahale gören (bakım) alan miktarı ve orman alanlarından verilen izin sayısı kullanılmıştır.

Şafak vd. (2014) Denizli Orman Bölge Müdürlüğü bünyesindeki orman işletme şefliklerinin etkinlik düzeylerini bulanık veri zarflama analiziyle tespit etmişlerdir. Çalışmada girdi değişkenleri olarak Ormanlık alanda yaşayan nüfus, toplam silvikültür harcamaları, genel üretim giderleri, toplam çalışan sayısı, ormanlık alan, yıllık izin verilen kesim alanı kullanılmıştır. Çıktı değişkenleri olarak toplam orman yolu uzunluğu, endüstriyel odun üretim miktarı, yanan alan miktarı, silvikültürel müdahale gören (bakım) alan miktarı ve orman alanlarından verilen izin sayısı kullanılmıştır.

Yukarıda özetlenen VZA'nın ormancıllk uygulamalarında kullanılan 77 adet girdi ve 70 adet çıktı değişken aşağıda Çizelge 2 verilmiştir. 
Çizelge 2. VZA çalışmalarında kullanılan girdi ve çıktı değ iş kenleri

\begin{tabular}{|c|c|c|}
\hline No & Girdi değişkenleri & Çıktı değişkenleri \\
\hline 1 & Hektar Başına Yılllk Bütçe (TL-Dolar) & Hektardaki Odun Uretim Miktarı $\left(\mathrm{m}^{3}\right)$ \\
\hline 2 & Başlangıç Yılında Hektardaki Servet Miktarı $\left(\mathrm{m}^{3}\right)$ & Hektar Başına Üretilen Odun D1şı Orman Ürünlerinin Parasal Değeri (TL-Dolar) \\
\hline 3 & Hektarda Kullanılan İşgücü Sayısı (kişi/ha) & Toprak Koruma (ha) \\
\hline 4 & Arazi Büyüklüğü (ha) & Hektardaki Yıllık Ziyaretçi Sayısı (kişi) \\
\hline 5 & Sermaye (TL-Dolar) & Haftalık Ortalama Toplam Üretim Miktarı $\left(\mathrm{m}^{3}\right)$ \\
\hline 6 & İşgücü Miktarı (kişi/ha) & Gazete Kâğ $d_{1}(\mathrm{~kg})$ \\
\hline 7 & Fabrika Sahibinin Yaşı (yıl) & Gazeteden Küçük Kâğıtlar (kg) \\
\hline 8 & Hasat Tipi (say1) & Afiș Kâğ $1 d_{1}(\mathrm{~kg})$ \\
\hline 9 & Üretim Dışında Çalışan İşgücü Miktarı (kişi/ha) & Kâğgt Hamuru (kg) \\
\hline 10 & Enerji Miktarı $(\mathrm{kW})$ & Toplam Hasılat (TL-Dolar) \\
\hline 11 & Kimyasallar (kg) & Toplan Net Kar (TL-Dolar) \\
\hline 12 & Odun Hamuru (kg) & Orman Sahipleri Birliğindeki Toplam Çalıșan Sayısı (kiși) \\
\hline 13 & Kâğ $1 t$ lık Odun $\left(\mathrm{m}^{3}\right)$ & Yillık Toplam Üretim Miktarı $\left(\mathrm{m}^{3}\right)$ \\
\hline 14 & Diğer Materyaller & Planlanan Orman Yolu Miktarı (km) \\
\hline 15 & Atık Kâğ 1 tlar (kg) & Denetimi Yapılan Orman Yolu İnşaatı $(\mathrm{km})$ \\
\hline 16 & Toplam Orman Sahipleri Birliği Üye Sayısı (kişi) & İncelenen ve Onaylanan Orman Yolu (km) \\
\hline 17 & 50 Hektar ve Üzerinde Orman Sahibi Sayısı (kişi) & Planlanan Drenaj Uzunluğu (km) \\
\hline 18 & Toplam Devamlı Orman İşçisi Sayısı (kişi) & Denetimi Yapılmış Drenaj Uzunluğu $(\mathrm{km})$ \\
\hline 19 & Birliğin Yetki Alanındaki Ormanlık Alan (ha) & İncelenen ve Onaylanan Drenaj Uzunluğu (km) \\
\hline 20 & Toplam Yatırım Gideri (TL-Dolar) & $\begin{array}{l}\text { Planlanan Bölgesel Orman Yönetimi Alan Olarak, Ev Yapımında ve Yakıt Olarak Kullanılacak } \\
\text { Ağac Yetistirmek İcin Orman Planlarında Ayrılan Yer Sayısı (adet) }\end{array}$ \\
\hline 21 & Aktifler Toplamı (TL-Dolar) & Orman Sahiplerinin Yüz Yüze İstedikleri Yardım Sayısı (adet) \\
\hline 22 & Üretimde Kullanılan Makine Sayısı (adet) & Grup Çalışmalarına Katılan Orman Sahibi Sayısı (kişi) \\
\hline 23 & $50 \mathrm{Kw}$ Üstündeki Kereste Makinesi (adet) & Orman Kurullarının Personeline Verdiği Kursların Toplam Gün Sayısı (adet) \\
\hline 24 & Toplam Depo Alan $1\left(\mathrm{~m}^{2}\right)$ & Onaylanmış Orman Islah Proje Sayısı (adet) \\
\hline 25 & Toplam Odun Üretimi $\left(\mathrm{m}^{3}\right)$ & Onaylanmış Rejenerasyon Proje Sayısı (adet) \\
\hline 26 & Toplam Ormanlaştırılan Alan (ha) & Üretilen Odun Miktarı $\left(\mathrm{m}^{3}\right)$ \\
\hline 27 & Toplam Açılan Alan (ha) & Y1llık Sermaye Fazlalığı (TL-Dolar) \\
\hline 28 & Toplam Tomruk Üretimi $\left(\mathrm{m}^{3}\right)$ & Bölge Ofislerinin Üyelerine Yarattığı Sermaye Fazlalığ $\breve{1}_{1}$ (TL-Dolar) \\
\hline 29 & Üretimde Bir Birimde Kullanılan Fiber (kg) & Bölge Ofisinin Üyelerine Yı1lık Fide Satış1 (adet) \\
\hline 30 & Yakıt $(\mathrm{kg})$ & Ağaçlandırma Alanı (ha) \\
\hline 31 & Elektrik Gücü $(\mathrm{kW})$ & Genç Orman Bakımı (ha) \\
\hline 32 & İşgücü (kişi) & Orman İçi Ağaçlandırma Alanı (ha) \\
\hline 33 & Ücret (TL-Dolar) & Koruma Firsat Değeri (say1) \\
\hline 34 & Hammadde (TL-Dolar) & Erişilebilirlik Değeri (sayı) \\
\hline 35 & Kimyasallar (kg) & Veri Tabanında Temsil Edilen Tür Sayısı (adet) \\
\hline 36 & Sermaye (TL-Dolar) & Kereste Üretimi $\left(\mathrm{m}^{3}\right)$ \\
\hline 37 & Sarf Malzeme Giderleri (TL-Dolar) & Yan Ürünlerin Parasal Değeri (TL-Dolar) \\
\hline 38 & Emek Ücreti (TL-Dolar) & Tahıl Üretim Değeri (TL-Dolar) \\
\hline 39 & Toplam Maliyetler (TL-Dolar) & Orman Ürünleri Değeri (TL-Dolar) \\
\hline 40 & Tarım Arazilerinin Satın Alma Maliyeti(TL-Dolar) & Hayvan Üretim Değeri (TL-Dolar) \\
\hline 41 & Koruma Çatışma Değeri(TL-Dolar) & Diğer Üretim Değerleri (TL-Dolar) \\
\hline 42 & Genel Üretim Giderleri (TL-Dolar) & Ücret (TL-Dolar) \\
\hline 43 & Araștırma ve Geliștirme Giderleri (TL-Dolar) & Kar (TL-Dolar) \\
\hline 44 & Genel Yönetim Giderleri (TL-Dolar) & Odun Hammaddesi Üretim Miktarı $\left(\mathrm{m}^{3}\right)$ \\
\hline 45 & Personel Sayısı (kişi) & Kurumsal Düzenlemeler \\
\hline 46 & Tahıl Üretiminde Kullanılan Arazi Büyüklüğü (ha) & Üretim Miktarı $\left(\mathrm{m}^{3}\right)$ \\
\hline 47 & Tahıl Üretimindeki Masraflar (TL-Dolar) & Orman Sınırının Tarım Arazilerine Olan Uzaklığı (km) \\
\hline 48 & Ormanc1lıktaki Masraflar (TL-Dolar) & Tarım Arazilerinin Merkeze Uzaklığ $1(\mathrm{~km})$ \\
\hline 49 & Hayvan Üretimi Masrafları (TL-Dolar) & Çiftçi Eğitim Y1lı (y1l) \\
\hline 50 & Diğer Masraflar (TL-Dolar) & Tütün Üretiminde Kullanılan Teknoloji \\
\hline 51 & İşçi Sayısı (kişi) & Çiftçi Deneyimi (y1l) \\
\hline 52 & Fonlar (TL-Dolar) & Kullanılan Arazi Tipi (sayı) \\
\hline 53 & Borçlar (TL-Dolar) & Tür Çeşitliliği İndeksi (sayı) \\
\hline 54 & Orman Kesim Alanı (ha) & Toplam Tütün Üretimi Maliyeti (TL-Dolar) \\
\hline 55 & Sermaye Değeri (TL-Dolar) & Tarımsal Arazi Fiyatı (TL-Dolar) \\
\hline 56 & Toplam Tütün Üretim Miktarı $(\mathrm{kg})$ & Gübre Fiyat1 (TL-Dolar) \\
\hline 57 & Yakacak Odun Miktarı $\left(\mathrm{m}^{3}\right)$ & Yakacak Odun Fiyatı (TL-Dolar) \\
\hline 58 & Arazi Miktarı (ha) & İşgücü Ücreti (TL-Dolar) \\
\hline 59 & Kullanılan Gübre Miktarı $(\mathrm{kg})$ & Yol Yoğunluğu $(\mathrm{km} / \mathrm{ha})$ \\
\hline 60 & İşletmenin Toplam Alanı (ha) & Silvikültür Çalışması Yapılan Alan Miktarı (ha) \\
\hline 61 & Toplam Ağaç Serveti $\left(\mathrm{m}^{3}\right)$ & Toplam Odun Satış Miktarı $\left(\mathrm{m}^{3}\right)$ \\
\hline 62 & Planlanmış Toplam Üretim Miktarı $\left(\mathrm{m}^{3}\right)$ & Brüt Satışlar Toplamı (TL-Dolar) \\
\hline 63 & İşletme Sorumluluk Alanı Nüfusu (kişi) & Dönen Varlıklar Toplamı (TL-Dolar) \\
\hline 64 & Toplam Orman Yangını Gideri (TL-Dolar) & Üretim Miktarı $\left(\mathrm{m}^{3}\right)$ \\
\hline 65 & Üretilen Toplam Odun Miktarı $\left(\mathrm{m}^{3}\right)$ & Dönem Kârı (TL-Dolar) \\
\hline 66 & Giderler Genel Toplamı (TL-Dolar) & Duran Varlıklar Toplamı (TL-Dolar) \\
\hline 67 & Sermaye (TL-Dolar) & Satıș Gelirleri (TL-Dolar) \\
\hline 68 & Toplam Alan (ha) & Satış Miktarı $\left(\mathrm{m}^{3}\right)$ \\
\hline 69 & Ormanlık Alan (ha) & Katma Değer (TL-Dolar) \\
\hline 70 & Verimli Orman Alanı (ha) & Ormanlardan verilen izin sayısı (adet) \\
\hline 71 & Üretim Maliyetleri (TL-Dolar) & \\
\hline 72 & Teknik Eleman Miktarı (kişi) & \\
\hline 73 & Çalışan Giderleri (TL-Dolar) & \\
\hline 74 & Toplam Çalışan Sayısı (kişi) & \\
\hline 75 & Silvikültür giderleri (TL) & \\
\hline 76 & Yangin Arac1 (adet) & \\
\hline 77 & Dikili satış miktarı $\left(\mathrm{m}^{3}\right)$ & \\
\hline
\end{tabular}


Çizelge 2 incelendiğinde, VZA yönteminin birimlerinin birbirinden farklı birçok değişkenin kullanımına olanak verdiği görülmektedir. Ayrıca girdi ve çıktı değişkenleri çalışmanın amacına göre de farklılık göstermektedir. Bir çalışmada girdi durumda olan bir değişken diğer bir çalışmada çıktı olarak kullanılmaktadır. $\mathrm{Bu}$ durum araştırmacılara kolaylık sağlamakla birlikte VZA'nın özellikle etkinlik ölçümü çalıșmalarında kullanımının artmasına neden olmaktadır.

\section{Sonuç ve öneriler}

Özellikle 1900'lü yılların başından itibaren işletmecilik alanında ortaya çıkan yeni yaklaşımlarla birlikte işletmeler çevreleri ile sürekli ilişki halinde olan açık sistemler olarak ele alınmaya başlanmıştır. Bununla birlikte işletmelerin sahip oldukları kaynakları, kullandıkları teknoloji ve çevresel faktörleri dikkate alarak etkin ve verimli bir şekilde kullanmalarının da önemi artmıştır. Bu durum neticesinde ișletmelerin etkinlik düzeylerinin ölçülmesi konusu da gelişim göstererek bu konuda çeşitli yöntemlerin ortaya çıkmasına sebep olmuştur. Kar amacı gütmeyen kamu iș letmelerinin etkinlik düzeylerinin belirlenmesine yönelik kullanılan Veri Zarflama Analizi bu yöntemlerin başında gelmektedir. $\mathrm{Bu}$ yöntem etkin olan işletmeleri belirlemesinin yanında etkin olmayan ișletmelerin niçin etkin olmadığını ve etkin olabilmeleri için neler yapması gerektiğini ortaya koymakta, özellikle de karar vericilere yol gösterebilmektedir.

Türkiye'de DOI'lerin başarı düzeylerinin ölçülmesine yönelik yapılan çalışmalarda genellikle DOI'lerin ekonomik fonksiyonları üzerinde durulmuştur. Ormanların odun hammaddesi üretiminin yanında sağladığ 1 ekolojik ve sosyal fonksiyonlarının da parasal değerlerinin hesaplanarak bu değerlemelere dahil edilmesi gerekmektedir. Bu kapsamda DOI'lere kanunlarca yüklenmiş olan sosyal amaçlar çoğu zaman ulaşmaları gereken ekonomik amaçların önüne geçmektedir. Özellikle DOİ'nin başarı düzeylerinin belirlenmes inde bu durumunda gözönünde bulundurulmas 1 gerekmektedir.

VZA, birimi birbirinden farklı birçok girdi ve çıktı değişkeninin aynı anda kullanılabilmesine imkan vermesinin yanında özellikle ormancılık gibi doğaya açık ve değişken sayıs ının çok olduğu alanlarda karar vericilere uygulama ve yorumlama kolaylığ 1 sağlamaktadır. Bu nedenle Türkiye'de ormanların işletilmesinde temel birimler olan DOI'lerin etkinlik düzeylerini ölçmede VZA'nın daha çok kullanılması ormanlarımız ve ormancılık örgütü açısından fayda sağlayacaktır.

\section{Teşekkür}

$\mathrm{Bu}$ makale KTÜ Bilimsel Araștırma Projeleri Koordinas yon Birimine ait 2010.113.001.2 nolu proje olarak desteklenen Devlet Orman İşletmelerinin Başarı Düzeylerinin Ölçülmesi ve Optimal İşletme Büyüklüğünün Belirlenmesi (Doğu KaradenizBölgesi Örneği) adlı doktora tezinin bir bölümünden türetilmiştir.

\section{Kaynaklar}

Aktaş, H., 2001. İşletme performansının ölçülmesinde veri zarflama analizi yaklaşımı, Celal Bayar Üniversitesi, İktis adi İdari Bilimler Fakültesi Dergisi, 7(1): 163-175.

Alım, E., 2004. Veri zarflama analizi ve orman yönetiminde bir uygulama. Yüksek Lisans Tezi, Gazi Üniversitesi, Fen Bilimleri Enstitüsü, Ankara.

Arslan, A., 2002. Kamu Harcamalarında Verimlilik, Etkinlik ve Denetim, Maliye Dergisi, 140(2): 1-14.

Avc1, B., 2004. İşletmeler aras1 göreli etkinlik ölçüm yaklaşımı: Veri zarflama analizi ve uygulaması. Yüksek Lisans Tezi, Uludağ Üniversitesi, Sosyal Bilimler Enstitüsü, Bursa.

Balteiro, L.D., Herruzo, A.C., Martinez, M., Pachon, J.G., 2006. An analysis of produxtive efficiency and innovation activity using DEA: An application to spain's wood-based industry. Forest Policy and Economics, 8:762-773.

Başar, M., Tosunoğlu, Ş., Kılıças lan, Y., 2009. Türkiye'de döner sermaye işletmelerinin etkinlik analizi: sorunlar, çözümler ve politika önerileri. TÜBİTAK Projesi, Proje No: 107K552, Ankara.

Bates, J.M., Baines, D., Whynes, D.K., 1996. Measuring the efficiency of prescribing by general practitioner. .Journal of the Opretaional Research Society, 47:14431451.

Bayazitlı, E., Çelik, O., 2004. Muhasebe eğitiminin kalitesinin artırılmasında ilk adım: yükseköğretim kurumlarında muhasebe eğitiminin etkinliğinin analizi, İstanbul Üniversitesi, Sürekli Yayınları, İstanbul.

Bayramoğlu, M.M., 2013. Devlet orman işletmelerinin başarı düzeylerinin ölçülmesi ve optimal işletme büyüklüğünün belirlenmesi (Doğu Karadeniz Bölgesi Örneği) Doktora Tezi, Karadeniz Teknik Üniversitesi, Fen Bilimleri Enstitüsü, Trabzon.

Bogetoft, P., Strange. N., Thorsen. B.J., 2001. Efficiency and merger gains in the danish forestry extension service. The Royal Veterinary and Agricultural University. Food and Resource Economic Institute. Units of Economics Working Papers, Frederiksberg C, Denmark.http://ageconsearch.umn.edu/bitstream/24210/ 1/ew010008.pdf Erişim:15/01/2017.

Boussofianee, A., Dyson. R., Rhodes. E., 1991. Applied data envelopment analysis. European Journal of Operational Research, 52:1-15.

Carter, R., Cubbage, D. F. W., 1995. Stochastic frontier estimation and sources of technical efficiency in southern timber harvesting. Forest Science, 41(3):576593.

Charnes, A., Cooper, W.W., Rhodes, E., 1981. Evaluating program and managerial efficiency: an application of data envolopment analysis to program follow through. Management Science, 27(6): 668-697.

Charnes, A., Cooper, W. W., Li, S., 1989. Using data envelopment analysis to evaluate efficiency in the economic performance Chinese cities. Socio-Economic Planning Sciences, 23(6): 325-344.

Çağlar, A., 2003. Veri zarflama analizi ile belediyelerin etkinlik ölçümü. Doktora Tezi, Hacettepe Üniversitesi, Fen Bilimleri Enstitüsü, Ankara. 
Çekin, İ.,1999. Veri zarflama yönteminin uygulamaya hazırlanması. Milli prodüktivite Merkezi Verimlilik Ölçme ve İzleme Bölümü, Ankara.

Çingi, S., Tarım, A., 2000. Türk bankacılık sisteminde performans ölçümü. DEA-Malmqoist TFP endeksi uygulamas 1. Hacettepe Üniversitesi İIBF Dergisi, 18:1734.

Çukur, S., 2005. Türk ticari bankacıllk sisteminde etkinlik analizi. İktis at İșletme ve Finans, 20(233):17-27.

Delikdaş, E., 2002. Türkiye özel sektör imalat sanayinde etkinlik ve toplam faktör verimliliği analizi. ODTÜ Geliştirme Dergisi, 29(3-4):247-284.

Demirci, A., 2012. OECD üyesi ülkelerin ekonomik ve sosyal etkinliklerinin veri zarflama analizi yöntemiyle belirlenmesi. Doktora Tezi, Atatürk Üniversitesi, Sosyal Bilimler Enstitüsü, Erzurum.

Deniz, N., 2009. Türkiye'deki illerin kaynak kullanımlarına göre göreli etkinliklerinin klasik ve bulanık veri zarflama analizi yöntemleri ile belirlenmesi. Yüksek Lisans Tezi, Anadolu Üniversitesi, Fen Bilimleri Enstitüsü, Eskişehir.

Depren, Ö., 2008. Veri zarflama analizi ve bir uygulama. Yüksek Lisans Tezi, Yıldız Teknik Üniversitesi, Fen Bilimleri Enstitüsü, İstanbul.

Gözü, C., 2003. Veri zarflama analizi ile etkinlik ölçümü ve tekstil işletmelerine yönelik bir uygulama. Yüksek Lisans Tezi, Ankara Üniversitesi Sosyal Bilimler Enstitüsü, Ankara.

Hseu, J.S., Buongiorno, J., 1995. Producer behavior and technology in the pulp and paper industries of the United States and Canada: A Nonparametric Analysis. Forest Science, 41(1):140-156.

Illukpitiya, S., 2005. Technical efficiency in agriculture and dependency on forest resources: An economic analysis of rural households and the conservation of natural forests in Sri Lanka. EEPSEA Publications. University of Hawaii, USA.

Joro, T., Viitala, E.J., 1999. The efficiency of public forestry organizations: A comparison of different weight restriction approaches. International Institute for Applied Systems Analysis (IIASA). Interim Report, Austria.

Kao, C., 1998. Measuring the efficiency of forest districts with multiple working circles, Journal of the Operational Research Society, 49:583-590.

Kao, C., 2000a. Short-run long-run efficiency measures for multiplant firms. Annals of Operational Research, 97:379-388.

Kao, C., 2000b. Measuring the performance improvement of Taiwan forests after reorganization. Forest Science, 46(4):577-584.

Kao, C., 2000c. Data envelopment analysis in resource allocation: An application to forest management, 31(9):1059-1066.

Kao, C., Yang, Y., 1991. Measuring the efficiency of forest management. Forest Science, 37(5):1239-1252.

Kao, C., 2009. Efficiency measurement for paralel production systems. European Journal of Operational Research, 196:1107-1112.

Kara, O., Kayacan, B., Eratilla, M., 2013. Düzce ili devlet orman işletme müdürlüklerinin parametrik olmayan yöntemlerle etkinliğinin analizi. Ekonomik ve Sosyal Araştırmalar Dergisi, 9(1): 97-123.
Karagöz, Y., Ekici, S., 2004. Sosyal bilimlerde yapılan uygulamalı araştırmalarda kullanılan istatistiksel teknikler ve ölçekler. Cumhuriyet Üniversitesi İktisadi ve İdari Bilimler Dergisi, 5(1):25-43.

Karsak, E.E., İşcan, F., 2000. Çimento sektöründe göreli faaliyet performanslarının ağırlıklı kısıtlamaları ve çapraz etkinlik kullanılarak veri zarflama analizi ile değerlendirilmesi. Endüstri Mühendis liği Dergisi, 11(3): 2-10.

Kaya, P., Erdoğan Aktan, H., 2011. Türk tarım sektörü verimliliğinin parametrik olmayan bir yöntemle analizi. Ulus lararası Alanya İş letme Fakültesi Dergisi, 3(1):261282.

Kaynar, O., 2004. Veri zarflama analizi ve göreceli etkinlik analizi üzerine bir uygulama. Doktora Tezi, Cumhuriyet Üniversitesi, Sosyal Bilimler Enstitüsü, Sivas.

Kecek, G., 2010. Veri zarflama analizi teori ve uygulama örneği. Siyas al Kitapevi, Ankara.

Kıran, B., 2008. Kalkınmada öncelikli illerin ekonomik etkinliklerinin veri zarflama analizi yöntemi ile değerlendirilmesi. Yüksek Lisans Tezi, Çukurova Üniversitesi, Sosyal Bilimler Enstitüsü, Adana.

Koopmans, T.C., 1951. Analysis of production as an efficient combination of activities. In: Koopmans, T.C (Ed.), Activity analysis of production and allocation, John Wiley and Sons Inc., New York.

Korkmaz, M., 2011. Measuring the productive efficiency of forest enterprises in mediterranean region of turkey using data envelopment analysis. African Journal of Agricultural Research, 6(19):4522-4532.

Lebel, L., Stuart, G.W.B., 1998. Technical efficiency evaluation of logging contractors using a nonparametric model. Journal of Forest Engineering, 9(2):15-24

Lien, G., Stordal, S., Baardsen, S., 2006. Private forest owners harvesting behaviors and technical efficiency: Effects of other income sources. Small-scale forestry and rural development: The intersection of ecosystems. Economics and Society, 18-23 June 2006, Galway, Ireland, pp:239-248.

Liu, C., Yin, R., 2004. Poverty dynamics revealed in production performance and forestry in improving livelihoods: The case of west Anhui. China. Forest Policy and Economics, 6:391-401.

Nyrud, A.Q., Bergseng, E.R., 2002. production efficiency and size in norwegian sawmilling. Scandinavian Journal of Forest Research, 17(6): 566-575.

Onaran, S., 2006. Veri zarflama analizi kullanılarak üniversite kütüphanelerinin performanslarının değerlendirilmesi. Yüksek Lisans Tezi, Gazi Üniversitesi, Fen Bilimleri, Ankara

Oruç, K.O., 2008. Veri zarflama analizi ile bulanık ortamda etkinlik ölçümleri ve üniversitelerde bir uygulama. Doktora Tezi, Süleyman Demirel Üniversitesi, Sosyal Bilimler Enstitüsü, Isparta.

Özdamar, K., 2002. Paket programlar ile istatistiksel veri analizi. Kaan Kitabevi, Eskişehir.

Öztürk, A., 2007. Yöneylem araştırması. Ekin Basım Yayım Dağıtım, Bursa.

Özyiğit, T., Serars lan. M.N., Karsak, E.E., 2008. Türkiye’de elektrik üretimi için enerji kaynaklarının etkinliğinin değerlendirilmesi. İstanbul Teknik Üniversitesi Dergisi, 7(5): 55-66. 
Paradi, J.C., Schaffnit, C., 2004. Commercial branch performance evaluation and results communication in a Canadian bank - A dea application. European Journal of Operational Research,156(3): 719-735.

Sauer, J., Abdallah, J.M., 2007. Forest diversity. Tobacco Production and Resource Management in Tanzania. Forest Policy and Economics, 9:421-429.

Shiba, M., 1997. Measuring the efficiency on managerial and technical performances in forestry activities by means of data envelopment analysis (DEA). Journal of Forest Engineering, 8(1):7-19.

Strange, N., 2003. Cost and preference based selection of biodiversity sites. 10th Ulvön Anniversary Conference on Environmental Economics \& Karl-Gustaf Löfgren Symposium, Ulvön. Sweden, pp. 22.

Subhash, C.R., 2004. Data envelopment analysis: Theory and techniques for economic and operations research. Cambridge University Press, Newyork.

Şafak, İ., 2009. Ege Bölgesi orman işletmelerinin etkinlik düzeylerinin değerlendirilmesi. Doktora Tezi, Celal Bayar Üniversitesi, Sosyal Bilimler Enstitüsü, Isparta.

Şafak, İ., Gül, A.U., Akkaş, M., E., Gediklili, M., Kanat, Ş.M., Portakal, S.Ü., 2012. Orman işletme şefliklerinin etkinliğinin bulanık veri zarflama yöntemi ile belirlenmesi (Denizli, İzmir ve Muğla Orman Bölge Müdürlüğü Örneği). TÜBİTAK, Proje No: 110O126; Başlama Bitiș:15.10.2010- 15.10.2012.

Şafak, İ., Gül, A.U., Akkaş, M.E., Portokal, S.Ü., Gediklili, M., Kanat, Ş.M., 2013. efficiency determination of the forest subdistricts by using fuzzy data envelopment analysis (Case Study: İzmir Forest Regional Directorate). Eurasian Journal of Forest Science, 1(1): 119.

Şafak, İ., Gül, A.U., Akkaş, M.E., Gediklili, M., Kanat, Ş.M., Portakal, S.Ü., 2014. Efficiency determination of the forest sub-districts by using fuzzy data envelopment analysis (Case Study: Denizli Forest Regional Directorate). International Journal of Fuzzy Systems, Vol. 16 (3):358-367.

Tarım, A., 2001. Veri zarflama analizi matematiksel programlama tabanlı göreli etkinlik ölçüm yaklaşımı. Sayıştay Yayınları, Ankara.
Thanassoulis, E., Boussofiane, A., Dyson, R.G., 1996. A comprasion of data envelopment analysis and ratio analysis as tools for performance assessment. Omega, 24(3):229-244.

Üte, E., 2002. Veri zarflama analizi tekniği ile sağlık sektörünün operasyonel etkinliğinin araştırılmas1. Yüksek Lisans Tezi, Çukurova Üniversitesi, Sosyal Bilimler Enstitüsü, Adana.

Viitala, E.J., Hänninen, H., 1998. Measuring the efficiency of public forestry organizations. Forest Science, 44(2):298-307.

Yalama, A., Sayım, M., 2008. Veri zarflama analizi ile imalat sektörünün performans değerlendirilmesi. Dokuz Eylül Üniversitesi İktisadi ve İdari Bilimler Fakültesi Dergisi, 23(1):89-107.

Yaşa, A., 2008. Bankacıllk sektöründe etkinlik ve veri zarflama analizi yöntemi ile ölçülmesi. Yüksek Lisans Tezi, Ankara Üniversitesi, Sosyal Bilimler Enstitüsü, Ankara.

Yaylalı, M., 2004. Mikro iktisat. 3. Baskı, Beta Yayınlanı, İstanbul.

Yeni, A., 2012. Türkiye broyler sektöründe üretim kümeslerinin ekonomik yapısı ve etkinlik analizi: doğu marmara bölgesi örneği. Doktora Tezi, Atatürk Üniversitesi, Sosyal Bilimler Enstitüsü, Erzurum.

Yin, R., 1998. DEA: A new methodology for evaluating the performance of forest products producers. Forest Products Journal, 48(1): 29-34.

Yolalan, R., 1993. işletmelerarası göreli etkinlik ölçümü. Milli Prodüktivite Yayınları, Ankara.

Yükçü, S., Atağan, G., 2009. Etkinlik, etkililik ve verimlilik kavramlarının yarattığ 1 karışıklık. Atatürk Üniversitesi İktis adi ve İdari Bilimler Dergisi, 23(4):1-13.

Zeydan, M., 2005. İMKB'de yer alan bankaların verimliliğinin DEA (Veri Zarflama Analizi) yöntemi kullanılarak belirlenmesi. Active Bankacıllk ve Finans Dergisi, 44:2.

Zhang, Y., 2002. The impacts of economic reform on the efficiency of silviculture: A non-parametric approach. Environment and Development Economics, 7:107-122. 